\title{
High-density Lipoproteins Induce the Migration Capacity of Mesenchymal Stromal Cells
}

Frank Spillmann¹, Kapka Miteva ${ }^{2}$, Katrin Warstat ${ }^{2}$, Stojan Perisic ${ }^{2}$, Jochen Ringe ${ }^{2,3}$, Carsten Tschöpe ${ }^{1,2 \#}$ and Sophie Van Linthout ${ }^{2 \star, \#}$

${ }^{1}$ Charité-University-Medicine Berlin, Campus Benjamin Franklin, Department of Cardiology, Berlin, Germany

${ }^{2}$ Charité-University-Medicine Berlin, Campus Virchow, Berlin-Brandenburg Center for Regenerative Therapy (BCRT), Berlin, Germany

${ }^{3}$ Laboratory for Tissue Engineering, Charité, University Medicine Berlin, Berlin, Germany

"contributed equally

\begin{abstract}
Background: Based on the regenerative capacity of $\mathrm{HDL}$ and their ability to induce migration of endothelial cells, we aimed to investigate whether HDL can influence the migration of mesenchymal stromal cells (MSC) and to analyze the underlying mechanisms.

Methods and results: MSC express the SR-BI receptor as shown by flow cytometry. Supplementation of HDL or their main apolipoprotein (apo), apo A-I, induces the phosphorylation state of Akt and NO production in MSC. This is associated with an increase in lamellipodia formation as demonstrated via phallotoxin staining and further leads to an induction in migration capacity as indicated by a 1.4-fold $(p<0.05)$ and 1.4-fold $(p<0.05)$ higher presence of MSC in the lower chamber of a modified Boyden chamber supplemented with HDL or apo A-I, respectively, compared to basal medium. In addition, the migration capacity of MSC in a wound healing assay $24 \mathrm{~h}$ after scratching was 1.7fold $(p<0.05)$ and 1.2 -fold $(p<0.05)$ higher in HDL-and apo A-I-supplemented hydroxyurea-treated MSC compared to basal hydroxyurea-treated MSC. In both assays, the HDL or apo A-I stimulated migration of MSC was reduced in the presence of the phosphatidylinositol-3-kinase (PI3K) inhibitor Ly294002.
\end{abstract}

Conclusion: $\mathrm{HDL}$ induces the migration of MSC in a PI3K-dependent manner.

Keywords: Mesenchymal stromal cells; HDL; Migration

Abbreviations: Apo A: I Apolipoprotein A-I; HDL: HighDensity Lipoproteins; MSC: Mesenchymal Stromal Cells; PI3K: phosphatidylinositol-3-Kinase

\section{Introduction}

Epidemiological studies [1,2] and studies in experimental animal models [3-5] consistently demonstrate that low high-density lipoprotein (HDL) cholesterol levels are a cardiovascular risk factor. The cardiovascular-protective effects of HDL have mainly been attributed to the role of HDL in "reverse cholesterol transport", the transport of excess of cholesterol from the periphery towards the liver. Though, meanwhile also the pleiotropic effects, including the anti-oxidative [6], anti-inflammatory $[4,7,8]$, anti-apoptotic $[9,10]$, and pro-angiogenic [11] features of HDL are well recognized. These effects are particularly attributed to apolipoprotein (apo) A-I, the main apolipoprotein of HDL, which constitutes $70 \%$ of the protein content of HDL. Consequently, a strong correlation between apo A-I plasma concentrations and HDL cholesterol levels exists [12]. Besides the above mentioned pleiotropic effects, HDL also have a regenerative potential: they induce the mobilization of endothelial progenitor cells (EPC)/ circulating angiogenic cells from the bone marrow [5] and promote their incorporation at the site of endothelial damage [13,14].

Mesenchymal stromal cells (MSC) are attractive candidates for cell therapy given their immunomodulatory [15-17], anti-oxidative [15], anti-apoptotic [15], anti-fibrotic [15,16,18], pro-angiogenic [19-21] features and their capacity to migrate towards the site of injury [16,2224]. Their ability to preferentially engraft into inflamed or ischemic injury follows from experimental animal studies $[16,23]$ as well as from studies showing that endogenous MSC can be mobilized from the bone marrow and recruited into the inflamed [24] or ischemic [22] heart. This characteristic empowers their therapeutic efficacy and favors the intravenous application of MSC as administration route [25]. In fact, approximately half of the clinical trials with MSC involve the systemic administration of MSC into the vasculature [26]. The migratory capacity of MSC towards chemokines and growth factors has already been intensively studied [27]. Though, the impact of HDL on the migration of MSC has not been explored so far.

Based on the capacity of HDL to induce migration of endothelial cells and their regenerative potential, we aimed to investigate whether HDL can influence the migration of MSC.

\section{Materials and Methods}

\section{Mesenchymal stromal cell isolation and cell culture}

Human adult MSC were isolated from iliac crest bone marrow aspirates of normal male donors after their written approval. The aspiration of iliac crest bone marrow was approved by the ethical committee of the Charité-Universitätsmedizin Berlin (EA1/131/07). Aspirates (3-5 ml) were washed twice with phosphate buffered saline (PBS) (Biochrom, Berlin, Germany), and resuspended in Dulbecco's Modified Eagle's Medium (DMEM; Invitrogen) supplemented with $10 \%$ fetal bovine serum (FBS), $1 \%$ penicillin/streptomycin, $1 \%$ glutamine, $2 \%$ HEPES and $2 \mathrm{ng} / \mathrm{ml}$ of basic fibroblast growth factor

*Corresponding author: Sophie Van Linthout, $\mathrm{PhD}$, Berlin-Brandenburg Center for Regenerative Therapies, Charité - University of Medicine Berlin, Campus Virchow, Südstrasse 2, 13353 Berlin, Germany, Tel: +49-(0)30-450539486; Fax: +49-(0)30-450539409; E-mail: sophie.van-linthout@charite.de

Received January 23, 2014; Accepted February 20, 2014; Published February 22, 2014

Citation: Spillmann F, Miteva K, Warstat K, Perisic S, Ringe J, et al. (2014) Highdensity Lipoproteins Induce the Migration Capacity of Mesenchymal Stromal Cells. J Stem Cell Res Ther 4: 176. doi:10.4172/2157-7633.1000176

Copyright: @ 2014 Spillmann F, et al. This is an open-access article distributed under the terms of the Creative Commons Attribution License, which permits unrestricted use, distribution, and reproduction in any medium, provided the original author and source are credited. 
(Tebu-bio, Offenbach, Germany). Cells were purified using a percoll gradient at a density of $1.073 \mathrm{~g} / \mathrm{ml}$ (Biochrom). Next, cells were washed with PBS and then resuspended in complete DMEM. Cells were plated at a density of $3 \times 10^{5}$ cells $/ \mathrm{cm}^{2}$ and cultured under standard cell culture conditions. Medium was exchanged after 72 hours (h) and every 3 days thereafter. Reaching $90 \%$ confluence, cells were trypsinized and replated at a density of $5 \times 10^{3} \mathrm{cells} / \mathrm{cm}^{2}$.

MSC were stimulated with $5 \mu \mathrm{g}$ of HDL protein $/ \mathrm{ml}$ or $3.5 \mu \mathrm{g} / \mathrm{ml}$ of apo A-I. Since previous in vitro experiments with HDL showed protective effects at $5 \mu \mathrm{g} / \mathrm{ml}[4]$ and $50 \mu \mathrm{g} / \mathrm{ml}[6,8,28]$ of HDL, we first compared the impact of 5 and $50 \mu \mathrm{g} / \mathrm{ml}$ of HDL on MSC migration. This experiment illustrated a more pronounced effect by $5 \mu \mathrm{g} / \mathrm{ml}$ (data not shown). We chose for $3.5 \mu \mathrm{g} / \mathrm{ml}$ of apo A-I, since apo A-I comprises $70 \%$ of HDL protein content.

Human aortic endothelial cells (HAEC) (Lonza Walkersville, Walkersville, MD, USA) were cultured in EBM-2 basal medium supplemented with EGM-2 Single Quots (Lonza, USA).

\section{Characterization of mesenchymal stromal cells}

MSC were characterized by flow cytometry analysis according to Binger et al. [29] with PE-labeled monoclonal mouse anti-human CD14, CD34, CD73, CD166 and FITC-labeled mouse anti-human CD44, CD45, CD90 and CD105 antibodies (Figure 1). Cells were washed with PBS-BSA $0.5 \%$, resuspended in $100 \mu$ of PBS-BSA $0.5 \%$ and incubated with titrated concentrations of antibodies at $4^{\circ} \mathrm{C}$ for 15 min. Prior to flow cytometry analysis, cells were washed with PBS-BSA $0.5 \%$.

\section{Scavenger receptor-BI flow cytometry}

MSC and HAEC, both in passage 5, were cultured in a 6-well plate until $90 \%$ confluence, and then trypsinized, collected, and resuspended in cold FACS buffer. Flow cytometry analysis was performed on a MACSQuant Miltenyi Biotec after cell labeling with rabbit polyclonal anti-SR-BI primary antibody (Novus Biologicals) and goat anti-rabbit IgG secondary antibody (Invitrogen) at $4^{\circ} \mathrm{C}$ for 60 minutes. SR-BI positive cells were analyzed with FlowJo 8.7. software (Tree Star).

\section{Western blot}

Three minutes (min) after stimulation with $5 \mu \mathrm{g} / \mathrm{ml}$ of HDL (MP
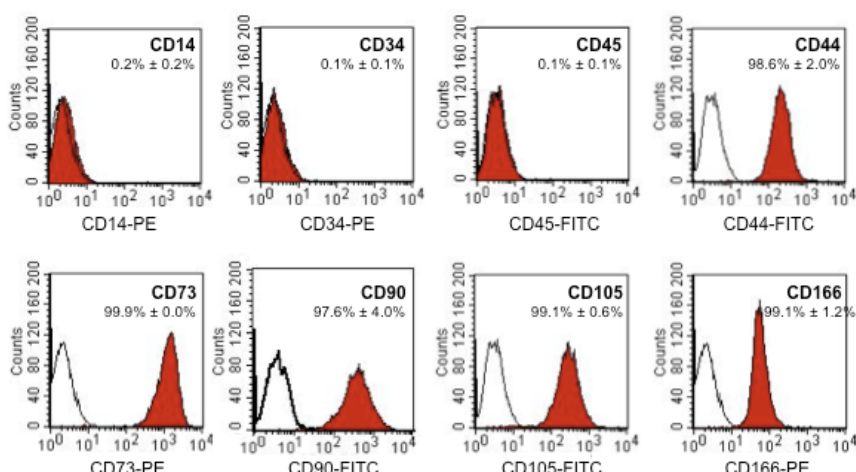

Figure 1: Representative flow cytometry analysis of mesenchymal stromal cells. Flow cytometry histograms indicate that MSC are CD14CD34-, CD45- and CD44+, CD73+, CD90+, CD105+ and CD166+. Numbers above the red histograms indicate the mean \pm SEM of the percentage $(\%)$ of gated cells which are positive of $n=3$ different donors.
Biomedicals, Solon, Ohio, USA) or $3.5 \mu \mathrm{g} / \mathrm{ml}$ of apo A-I (Sigma), cells were lysed in lysis buffer (Invitrogen) containing proteinase inhibitors (Roche). An equal amount of protein was loaded into a SDS-polyacrylamide gel. p-Akt and Akt antibodies (Cell signaling), and $\beta$ tubulin (Santa Cruz Biotechnology, Santa Cruz, CA, USA) were detected with the respective antibody, followed by incubation with an IR dye secondary antibody (LI-COR Biosciences, Lincoln/Nebraska, USA). All blots were visualized with Odyssey (LI-COR Biosciences). Quantitative analysis of the intensity of the bands was performed with Odyssey V3.0 software.

\section{Nitric oxide measurement}

Intracellular NO was measured with DAF-FM diacetate (4-amino5-methylamino- $2^{\prime}, 7^{\prime}$-difluorofluorescein diacetate, Invitrogen) as described previously [30]. Following a pretreatment of $2 \mathrm{~h}$ with $1 \mu \mathrm{M}$ of the PI3K-inhibitor Ly 294002 (Calbiochem, EMD Chemicals, Gibbstown, NJ, USA) for all conditions with Ly 294002, MSC were supplemented with $5 \mu \mathrm{g} / \mathrm{ml}$ of HDL or $3.5 \mu \mathrm{g} / \mathrm{ml}$ of apo A-I for $5 \mathrm{~min}$ in the presence or absence of Ly 294002 . Next, MSC were incubated at $37^{\circ} \mathrm{C}$ for $30 \mathrm{~min}$ in PBS containing $1 \mu \mathrm{M}$ of DAF-FM diacetate. After loading, cells were rinsed two times with $\mathrm{PBS}$ and incubated with fresh $\mathrm{PBS}$ at $37^{\circ} \mathrm{C}$ for 30 min. NO fluorescence intensity was read in a Berthold Mithras LB 940 reader at $495 \mathrm{~nm}$ excitation and $515 \mathrm{~nm}$ emission wavelength.

\section{Lamellipodia formation}

MSC (7,500 cells/well) were plated in a CellCarrier black 96-well plate (PerkinElmer, Waltham, Massachusetts, USA). After 24h, cells were treated with $3.5 \mu \mathrm{g} / \mathrm{ml}$ apoA-I, or $5 \mu \mathrm{g} / \mathrm{ml} \mathrm{HDL}$ for $5 \mathrm{~min}, 10 \mathrm{~min}$, $15 \mathrm{~min}$ and $30 \mathrm{~min}$, respectively, and fixed with $4 \%$ paraformaldehyde. Twenty-four hours after fixation, MSC were stained with 3.6 $\mu \mathrm{M}$ DAPI (Sigma) and 6.9 $\mu \mathrm{M}$ phallotoxin (Alexa Fluor 546). Fluorescent images were taken by Operetta high content screening system (PerkinElmer, Inc. USA) using the 20x LWD objective. Cells with lamellipodia were evaluated from 3 to 4 fields with approximately 40-50 cells/field.

\section{Modified boyden chamber migration assay}

MSC migration was evaluated by using a modified Boyden chamber (Chemo TX ${ }^{\circ}$ Neuroprobe, Gaitherburg). After reaching confluency, MSC were seeded in the upper chamber at a density of $3 \times 10^{4}$ cells per well in $40 \mu \mathrm{l}$ of basal medium per well. A volume of $37.5 \mu \mathrm{l}$ of medium supplemented with $3.5 \mu \mathrm{g} / \mathrm{ml}$ apo A-I or $5 \mu \mathrm{g} / \mathrm{ml} \mathrm{HDL}$, with or without $1 \mu \mathrm{M}$ of Ly 294002 (Calbiochem) or 10\% FBS (positive control) with $\mathrm{n}=4$ per group was placed in the lower chamber. MSC were allowed to migrate for $24 \mathrm{~h}$ at $37^{\circ} \mathrm{C}$ and were subsequently stained by crystal violet. The migration of MSC was quantified by absorbance measurement at $595 \mathrm{~nm}$ with a spectrophotometer (Spectramax 340 PC', Molecular devices, USA).

\section{Wound healing assay}

MSC were seeded in 6-well plates at a density of $2 \times 10^{5}$ cells per well. After reaching confluency, the medium was subsequently replaced with serum starvation medium (DMEM medium containing $0.01 \%$ FBS, $1 \%$ penicillin/streptomycin), supplemented with $3.5 \mu \mathrm{g} / \mathrm{ml}$ apoA-I or $5 \mu \mathrm{g} / \mathrm{ml} \mathrm{HDL}$, in the presence or absence of $1 \mu \mathrm{M}$ of Ly294002. In all the conditions the anti-proliferative agent, hydroxyurea $(5 \mathrm{mM}$, Sigma), was added. MSC were allowed to migrate for $24 \mathrm{~h}$ at $37^{\circ} \mathrm{C}$ and the number of migrated MSC was quantified per microscopy field for $\mathrm{n}=10-12$. Migrated MSC were depicted as percentage (\%) with the amount of migrated MSC versus basal medium set as $100 \%$. 


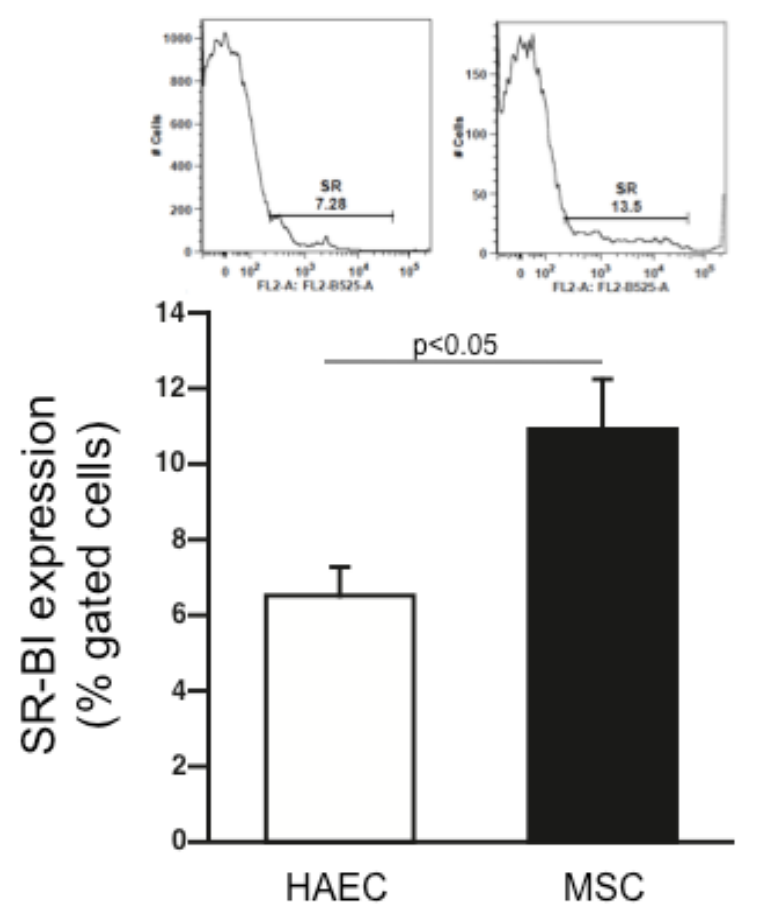

Figure 2: Mesenchymal stromal cells express the SR-BI receptor. Bar graph represents the mean \pm SEM of the percentage (\%) of SR-BI-positive human aortic endothelial cells (HAEC; open bars) and mesenchymal stromal cells (MSC; black bars), $n=5 /$ group.

\section{Statistical analysis}

Data are presented as mean \pm SEM. Paired and unpaired Student's $\mathrm{t}$ tests or Mann Whitney tests were used for statistical analysis. Differences were considered to be significant at $\mathrm{p}<0.05$.

\section{Results}

\section{HDL-mediated signalling in mesenchymal stromal cells}

Flow cytometry analysis demonstrated that MSC express the SRBI receptor (Figure 2). Supplementation of HDL and apo A-I induced phosphorylation of the downstream target Akt by 1.3 -fold $(\mathrm{p}<0.05)$ and 1.3 -fold $(\mathrm{p}<0.005)$, respectively (Figure $3 \mathrm{~A})$. NO production was 1.7 fold $(\mathrm{p}<0.001)$ and 1.5 -fold $(\mathrm{p}<0.01)$ induced upon HDL and apo A-I supplementation, respectively. This effect was abrogated by the PI3K inhibitor Ly294002, leading to NO levels not significantly different from basal levels (Figure 3B).

\section{HDL induce the migration capacity of mesenchymal stromal cells}

Supplementation of MSC with $5 \mu \mathrm{g} / \mathrm{ml}$ of HDL or $3.5 \mu \mathrm{g} / \mathrm{ml}$ of apo A-I induced lamellipodia formation in MSC by 2.0 -fold $(\mathrm{p}<0.01)$ and 1.8 -fold $(\mathrm{p}<0.05)$, respectively, $5 \mathrm{~min}$ after stimulation as indicated by phallotoxin staining (Figures $4 \mathrm{~A}$ and $4 \mathrm{C}$ ). This effect gradually decreased over time with no significant induction after $15 \mathrm{~min}$ (Figures $4 \mathrm{~B}$ and $4 \mathrm{D}$ ). The HDL- and apo A-I-mediated induction in lamellipodia was reflected in the raised migratory potential of MSC as shown by Boyden chamber and wound healing assays.

The amount of migrated MSC was 1.4 -fold $(\mathrm{p}<0.05), 1.4$-fold $(p<0.05)$, and 2.0 -fold $(p<0.05)$ higher in the lower chamber of the Boyden chamber containing $5 \mu \mathrm{g} / \mathrm{ml} \mathrm{HDL}, 3.5 \mu \mathrm{g} / \mathrm{ml}$ apo A-I (Figure
5A) or 10\% FBS (positive control; data not shown) compared to basal medium, respectively. Twenty-four hours after scratching and HDL or apo A-I stimulation in the presence of the anti-proliferative agent hydroxyurea, the migration capacity of MSC was 1.7 -fold $(\mathrm{p}<0.0001)$ and 1.2-fold $(\mathrm{p}<0.05)$ higher in HDL and apo A-I-supplemented MSC compared to hydroxyurea-treated MSC, respectively (Figures 5B and 5C). In both assays, the HDL or apo A-I stimulated migration of MSC was reduced in the presence of the PI3K inhibitor Ly294002.

\section{Discussion}

The salient finding of this study is that HDL and their main apolipoprotein, apo A-I, induce the migration of MSC in a PI3Kdependent manner.

MSC are an attractive cell source for cell therapy given their

A
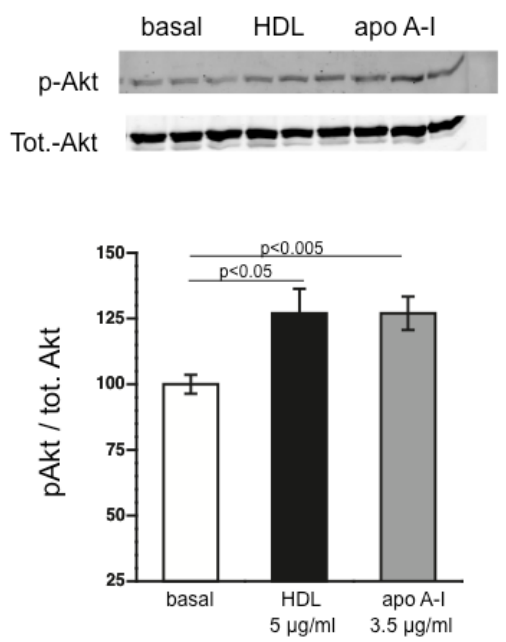

B

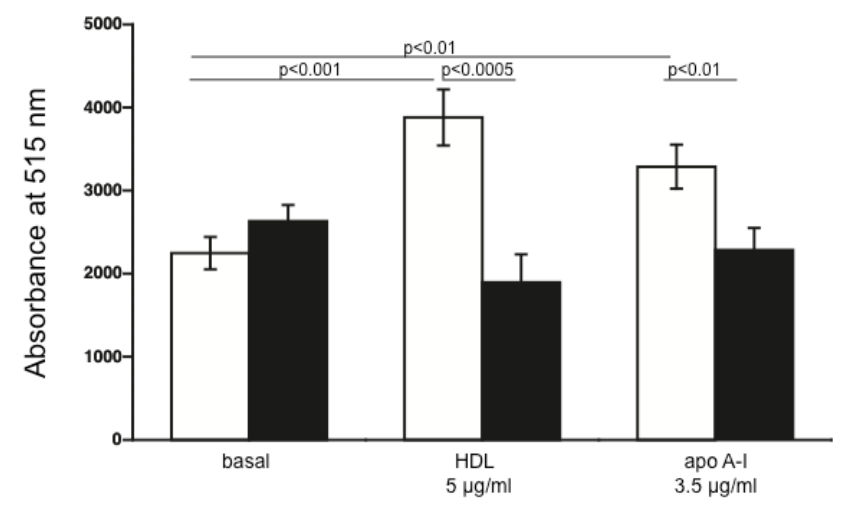

Figure 3: HDL and apo A-I supplementation induce the phosphorylation state of Akt and increase nitric oxide in mesenchymal stromal cells in a phosphatidylinositol-3-kinase-dependent manner. (A) Representative Western blots of p-Akt and Akt in MSC 3 min after HDL (black bar) or apo A-I (grey bar) supplementation. Bar graph represents the mean \pm SEM of the $\mathrm{p}$-Akt/Akt ratio expressed as the percentage of the non-stimulated basal group ( $n=10$ /group for basal, HDL, and $n=7$ for apo A-I). (B) Bar graphs representing the mean \pm SEM of intracellular NO production depicted as absorbance at $515 \mathrm{~nm}$ in untreated (open bars) MSC and MSC pre- and co-treated with the phosphatidyl-inositol-3-kinase inhibitor Ly 294002 (black bars) and supplemented with $5 \mu \mathrm{g} / \mathrm{ml}$ of $\mathrm{HDL}$ or $3.5 \mu \mathrm{g} / \mathrm{ml}$ of apo A-I for $5 \mathrm{~min}(\mathrm{n}=10 /$ group). 
Citation: Spillmann F, Miteva K, Warstat K, Perisic S, Ringe J, et al. (2014) High-density Lipoproteins Induce the Migration Capacity of Mesenchymal Stromal Cells. J Stem Cell Res Ther 4: 176. doi:10.4172/2157-7633.1000176

Page 4 of 6

A.
Control 5 min

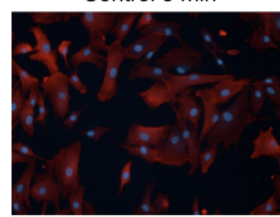

B.

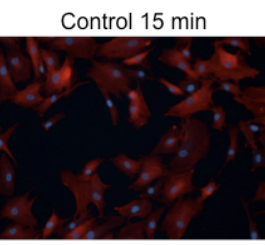

C.

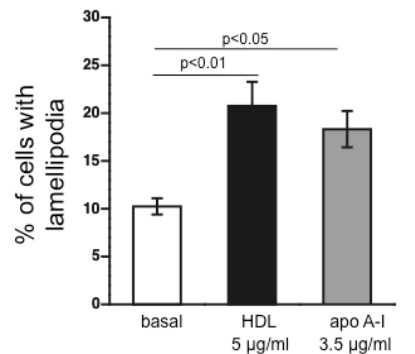

$\mathrm{HDL} 5 \mu \mathrm{g} / \mathrm{ml} 5 \mathrm{~min}$

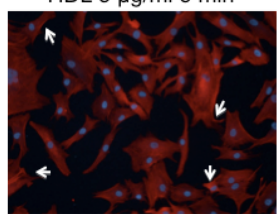

$\mathrm{HDL} 5 \mu \mathrm{g} / \mathrm{ml} 15 \mathrm{~min}$

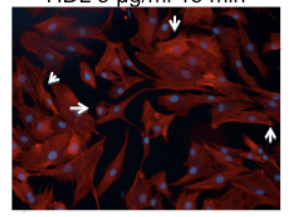

D.

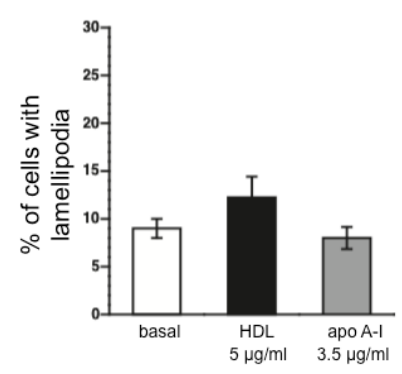

Figure 4: HDL and apo A-I induce lamellipodia formation in mesenchymal stromal cells. Representative images of MSC stimulated with HDL or apo A-I for (A) 5 or (B) 15 min. Arrows indicate lamellipodia. Red staining (Alexa Fluor 546) reveals the actin filaments and lamellipodia, whereas the blue staining (DAPI) indicates the cell nuclei. Bar graphs representing the mean \pm SEM of the $\%$ of cells with lamellipodia (C) 5 min or D. 15 min post HDL or apo A-I supplementation.

pleiotropic effects and their ability to migrate towards the site of tissue damage. This migration process involves the interaction between released chemokines/growth factors at the site of injury and chemokine receptors on the MSC, and depends on the viability and functionality of the MSC. Comorbidities like diabetes mellitus [31,32] and age [33] decrease the migration capacity of MSC, whereas cell culture conditions, including hypoxia [34] induce their migration potential. The impaired migration of MSC under diabetes mellitus is triggered by hyperglycemia-induced oxidative stress [31]. Though, under type 2 diabetes mellitus also dyslipidemia including high LDL cholesterol and low HDL cholesterol levels might underlie the reduced migration efficacy of MSC.

Several approaches directed at increasing the survival and functionality of MSC have been associated with activation of the PI3K/ Akt signaling pathway [35]. HDL has been shown to protect MSC from oxidative stress-induced apoptosis involving PI3K/Akt [36]. However, the impact of HDL on MSC migration has not been investigated so far.

We demonstrated that MSC express the SR-BI receptor and that 3 min post HDL or apo A-I supplementation, the phosphorylation state of Akt was upregulated. In addition, HDL-and apo A-I induced NO in MSC in a PI3K-dependent manner. The involvement of $\mathrm{NO}$ in downstream PI3K signaling and cell migration has been documented in several reports $[37,38]$. In agreement with the HDL-mediated migration of endothelial cells [11] and EPC [14,38], we next illustrated via modified
Boyden chamber migration and wound healing assays that HDL and apo A-I induce the migration of MSC in a PI3K-dependent manner. PI3K/Akt signaling regulates multiple biological processes including cell growth, cell division, survival [4], cell migration and invasion [39]. Particularly, Akt enhances actin remodeling and generates membrane protrusions through downstream activation of Rac1 and Cdc42 [40]. Via phallotoxin staining, we further demonstrated that both HDL and apo A-I induce cytoskeleton rearrangement, actin filament deposition in the proximity of the plasma membrane and pronounced lamellipodia

A.

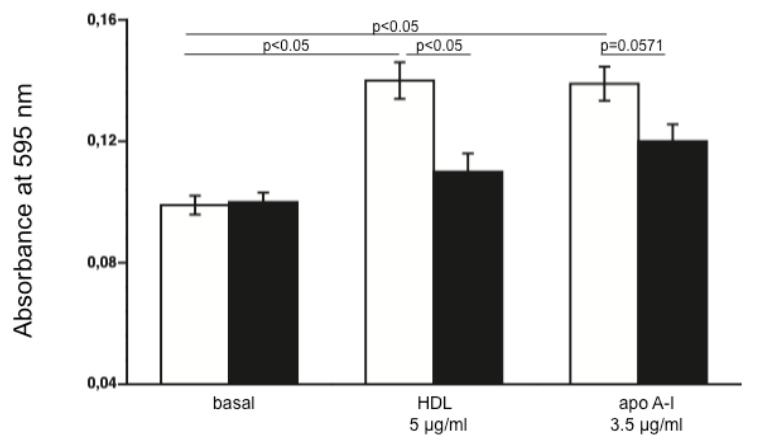

B.
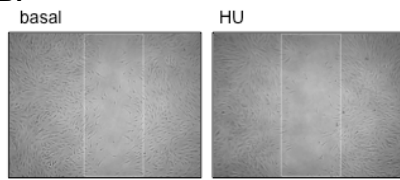

$\mathrm{HU}+\mathrm{Ly}$
$\mathrm{HU}+\mathrm{HDL}$

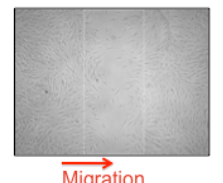

$H U+H D L+L y$

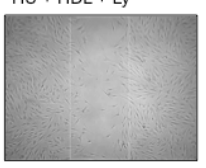

Migration

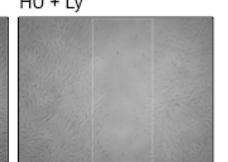

$\mathrm{HU}+\mathrm{Apo} \mathrm{A}-\mathrm{I}$

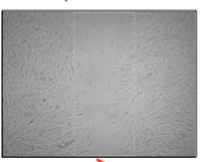

$\overrightarrow{\text { Migration }}$

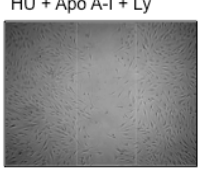

C.

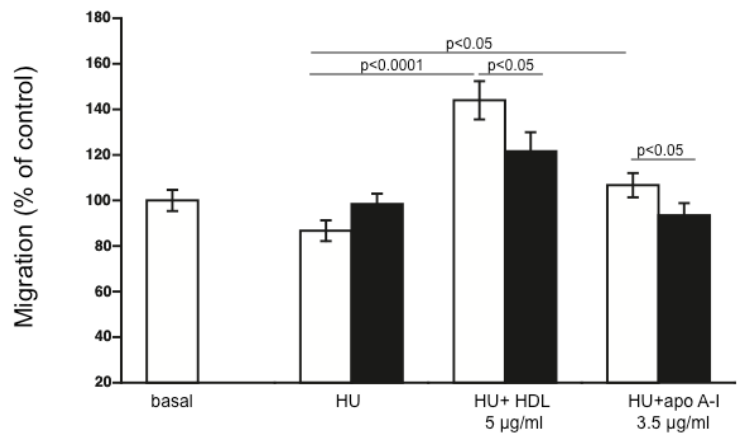

Figure 5: $\mathrm{HDL}$ and apo A-I induce migration of mesenchymal stromal cells in a phosphatidyl-inositol-3-kinase-dependent manner. (A) Bar graph represents the mean \pm SEM of the absorbance at $595 \mathrm{~nm}$ depicting the migration potential of MSC versus basal medium, HDL or apo A-I in the absence (open bars) or presence (black bars) of the phosphatidyl-inositol-3-kinase inhibitor Ly 294002 with $n=4$ /group. (B) Representative pictures of a wound healing assay showing MSC $24 \mathrm{~h}$ post-scratching and supplementation of basal medium, medium containing hydroxyurea (HU) with or without $\mathrm{HDL}$ or apo A-I in the absence or presence of Ly 294002 (Ly) as indicated. (C) Bar graph represents the mean \pm SEM of the percentage of migrating MSC $24 \mathrm{~h}$ after scratching and supplementation of basal medium, medium containing $\mathrm{HU}$ with or without $\mathrm{HDL}$ or apo A-I in the absence (open bars) or presence (black bars) of Ly 294002, expressed towards the percentage of the non-stimulated basal group set as 100. $n=10-12$ fields/group. 
Citation: Spillmann F, Miteva K, Warstat K, Perisic S, Ringe J, et al. (2014) High-density Lipoproteins Induce the Migration Capacity of Mesenchymal Stromal Cells. J Stem Cell Res Ther 4: 176. doi:10.4172/2157-7633.1000176

Page 5 of 6

formation, supporting the HDL/apo A-I mediated induction of MSC migration.

In summary, HDL and apo A-I enhance the migratory capacity of MSC involving PI3K - Akt. Therefore, we suggest that the HDLand apo A-I-induced improvement in MSC functionality facilitates circulating MSC to migrate towards the site of injury and to contribute to endothelial repair via their ability to render endothelial cells support as pericyte-like cell [41] and their capacity to induce angiogenesis in a paracrine manner [19]. We conclude that the regenerative capacity of HDL is broaden by their ability to improve the migration of MSC in a PI3K-dependent manner. Furthermore, this study supports the culture of MSC in the presence of HDL to improve their potency for clinical use.

\section{Acknowledgement}

This study was supported by the DZHK to CT and SVL and by the European Foundation for the Study of Diabetes (EFSD) to SVL. We would like to acknowledge the assistance of the BCRT Flow Cytometry Lab. We thank Annika Koschel and Gwendolin Matz (in alphabetical order) for excellent technical support.

\section{Disclosure}

There is no conflict of interest

\section{References}

1. Gordon T, Castelli WP, Hjortland MC, Kannel WB, Dawber TR (1977) High density lipoprotein as a protective factor against coronary heart disease. The Framingham Study. Am J Med 62: 707-714.

2. Gordon DJ, Probstfield JL, Garrison RJ, Neaton JD, Castelli WP, et al. (1989) High-density lipoprotein cholesterol and cardiovascular disease. Four prospective American studies. Circulation 79: 8-15.

3. Rubin EM, Krauss RM, Spangler EA, Verstuyft JG, Clift SM (1991) Inhibition of early atherogenesis in transgenic mice by human apolipoprotein Al. Nature 353: 265-267.

4. Van Linthout S, Spillmann F, Riad A, Trimpert C, Lievens J, et al. (2008) Human apolipoprotein A-I gene transfer reduces the development of experimental diabetic cardiomyopathy. Circulation 117: 1563-1573.

5. Feng Y, Jacobs F, Van Craeyveld E, Brunaud C, Snoeys J, et al. (2008) Human ApoA-I transfer attenuates transplant arteriosclerosis via enhanced incorporation of bone marrow-derived endothelial progenitor cells. Arterioscler Thromb Vasc Biol 28: 278-283.

6. Van Linthout S, Spillmann F, Lorenz M, Meloni M, Jacobs F, et al. (2009) Vascularprotective effects of high-density lipoprotein include the downregulation of the angiotensin II type 1 receptor. Hypertension 53: 682-687.

7. Van Linthout S, Spillmann F, Schultheiss HP, Tschöpe C (2010) High-density lipoprotein at the interface of type 2 diabetes mellitus and cardiovascular disorders. Curr Pharm Des 16: 1504-1516.

8. Van Linthout S, Spillmann F, Graiani G, Miteva K, Peng J, et al. (2011) Downregulation of endothelial TLR4 signalling after apo A-I gene transfer contributes to improved survival in an experimental model of lipopolysaccharide-induced inflammation. J Mol Med (Berl) 89: 151-160.

9. Suc I, Escargueil-Blanc I, Troly M, Salvayre R, Nègre-Salvayre A (1997) HDL and ApoA prevent cell death of endothelial cells induced by oxidized LDL. Arterioscler Thromb Vasc Biol 17: 2158-2166.

10. Radojkovic C, Genoux A, Pons V, Combes G, de Jonge H, et al. (2009) Stimulation of cell surface F1-ATPase activity by apolipoprotein A-I inhibits endothelial cell apoptosis and promotes proliferation. Arterioscler Thromb Vasc Biol 29: 1125-1130.

11. Seetharam D, Mineo C, Gormley AK, Gibson LL, Vongpatanasin W, et al (2006) High-density lipoprotein promotes endothelial cell migration and reendothelialization via scavenger receptor-B type I. Circ Res 98: 63-72.

12. Van Linthout S, Collen D, De Geest B (2002) Effect of promoters and enhancers on expression, transgene DNA persistence, and hepatotoxicity after adenoviral gene transfer of human apolipoprotein A-I. Hum Gene Ther 13: 829-840.

13. Tso C, Martinic G, Fan WH, Rogers C, Rye KA, et al. (2006) High-density lipoproteins enhance progenitor-mediated endothelium repair in mice. Arterioscler Thromb Vasc Biol 26: 1144-1149.

14. Feng Y, van Eck M, Van Craeyveld E, Jacobs F, Carlier V, et al. (2009) Critical role of scavenger receptor-Bl-expressing bone marrow-derived endothelial progenitor cells in the attenuation of allograft vasculopathy after human apo A-I transfer. Blood 113: 755-764.

15. Van Linthout S, Savvatis K, Miteva K, Peng J, Ringe J, et al. (2011) Mesenchymal stem cells improve murine acute coxsackievirus B3-induced myocarditis. Eur Heart J 32: 2168-2178.

16. Savvatis K, van Linthout S, Miteva K, Pappritz K, Westermann D, et al. (2012) Mesenchymal stromal cells but not cardiac fibroblasts exert beneficial systemic immunomodulatory effects in experimental myocarditis. PLOS One 7: e41047.

17. Ren G, Zhang L, Zhao X, Xu G, Zhang Y, et al. (2008) Mesenchymal stem cellmediated immunosuppression occurs via concerted action of chemokines and nitric oxide. Cell Stem Cell 2: 141-150.

18. Mias C, Lairez O, Trouche E, Roncalli J, Calise D, et al. (2009) Mesenchyma stem cells promote matrix metalloproteinase secretion by cardiac fibroblasts and reduce cardiac ventricular fibrosis after myocardial infarction. Stem Cells 27: $2734-2743$.

19. Hung SC, Pochampally RR, Chen SC, Hsu SC, and Prockop DJ (2007) Angiogenic effects of human multipotent stromal cell conditioned medium activate the PI3K-Akt pathway in hypoxic endothelial cells to inhibit apoptosis, increase survival, and stimulate angiogenesis. Stem Cells 25: 2363-2370.

20. Kinnaird T, Stabile E, Burnett MS, Shou M, Lee CW, et al. (2004) Loca delivery of marrow-derived stromal cells augments collateral perfusion through paracrine mechanisms. Circulation 109: 1543-1549.

21. Prather WR, Toren A, Meiron M, Ofir R, Tschope C, et al. (2009) The role of placental-derived adherent stromal cell (PLX-PAD) in the treatment of critical limb ischemia. Cytotherapy 11: 427-434

22. Kawada H, Fujita J, Kinjo K, Matsuzaki Y, Tsuma M, et al. (2004) Nonhematopoietic mesenchymal stem cells can be mobilized and differentiate into cardiomyocytes after myocardial infarction. Blood 104: 3581-3587.

23. Belema-Bedada F, Uchida S, Martire A, Kostin S, and Braun T (2008) Efficien homing of multipotent adult mesenchymal stem cells depends on FROUNTmediated clustering of CCR2. Cell Stem Cell 2: 566-575.

24. Escher F, Schmidt-Lucke C, Van Linthout S, Savvatis K, Schultheiss H-P et al. (2010) Cardiac migration of mesenchymal stem cells in patients with inflammatory cardiomyopathy. European Heart Journal Supplements 31: S 464-465.

25. Van Linthout S, Stamm Ch, Schultheiss HP, Tschöpe C (2011) Mesenchyma stem cells and inflammatory cardiomyopathy: cardiac homing and beyond Cardiol Res Pract 2011: 757154.

26. Ankrum J, Karp JM (2010) Mesenchymal stem cell therapy: Two steps forward one step back. Trends Mol Med 16: 203-209.

27. Kang SK, Shin IS, Ko MS, Jo JY, Ra JC (2012) Journey of mesenchymal stem cells for homing: strategies to enhance efficacy and safety of stem cell therapy. Stem Cells Int 2012: 342968.

28. Van Linthout S, Foryst-Ludwig A, Spillmann F, Peng J, Feng Y, et al. (2010) Impact of HDL on adipose tissue metabolism and adiponectin expression. Atherosclerosis 210: 438-444.

29. Binger T, Stich S, Andreas K, Kaps C, Sezer O, et al. (2009) Migration potentia and gene expression profile of human mesenchymal stem cells induced by CCL25. Exp Cell Res 315: 1468-1479.

30. Spillmann F, Van Linthout S, Miteva K, Lorenz M, Stangl V, et al. (2014) LXR agonism improves TNF-ît-induced endothelial dysfunction in the absence of its cholesterol-modulating effects. Atherosclerosis 232: 1-9.

31. Yang K, Wang XQ, He YS, Lu L, Chen QJ, et al. (2010) Advanced glycation end products induce chemokine/cytokine production via activation of p38 pathway and inhibit proliferation and migration of bone marrow mesenchymal stem cells. Cardiovasc Diabetol 9: 66

32. Shin L, Peterson DA (2012) Impaired therapeutic capacity of autologous stem cells in a model of type 2 diabetes. Stem Cells Transl Med 1: 125-135.

33. Kasper G, Mao L, Geissler S, Draycheva A, Trippens J, et al. (2009) Insights into mesenchymal stem cell aging: involvement of antioxidant defense and actin cytoskeleton. Stem Cells 27: 1288-1297. 
Citation: Spillmann F, Miteva K, Warstat K, Perisic S, Ringe J, et al. (2014) High-density Lipoproteins Induce the Migration Capacity of Mesenchymal Stromal Cells. J Stem Cell Res Ther 4: 176. doi:10.4172/2157-7633.1000176

34. Rosová I, Dao M, Capoccia B, Link D, Nolta JA (2008) Hypoxic preconditioning results in increased motility and improved therapeutic potential of human mesenchymal stem cells. Stem Cells 26: 2173-2182.

35. Chen J, Crawford R, Chen C, Xiao Y (2013) The key regulatory roles of the $\mathrm{PI} 3 \mathrm{~K} / \mathrm{Akt}$ signaling pathway in the functionalities of mesenchymal stem cells and applications in tissue regeneration. Tissue Eng Part B Rev 19: 516-528.

36. Xu J, Qian J, Xie X, Lin L, Zou Y, et al. (2012) High Density Lipoprotein Protects Mesenchymal Stem Cells from Oxidative Stress-Induced Apoptosis via Activation of the PI3K/Akt Pathway and Suppression of Reactive Oxygen Species. Int J Mol Sci 13: 17104-17120.

37. Chen X, Chen Q, Wang L, Li G (2013) Ghrelin induces cell migration through GHSR1a-mediated PI3K/Akt/eNOS/NO signaling pathway in endothelial progenitor cells. Metabolism 62: 743-752.
38. Segal MS, Sautina L, Li S, Diao Y, Agoulnik Al, et al. (2012) Relaxin increases human endothelial progenitor cell NO and migration and vasculogenesis in mice. Blood 119: 629-636.

39. Manning BD, Cantley LC (2007) AKT/PKB signaling: navigating downstream Cell 129: $1261-1274$

40. Cenni V, Sirri A, Riccio M, Lattanzi G, Santi S, et al. (2003) Targeting of the Akt/ PKB kinase to the actin skeleton. Cell Mol Life Sci 60: 2710-2720.

41. Covas DT, Panepucci RA, Fontes AM, Silva WA Jr, Orellana MD, et al (2008) Multipotent mesenchymal stromal cells obtained from diverse human tissues share functional properties and gene-expression profile with CD146+ perivascular cells and fibroblasts. Exp Hematol 36: 642-654. 